\title{
THE EFFECT OF CORPORATE GOVERNANCE MECHANISM ON EARNINGS MANAGEMENT PRACTICE (Case Study on Indonesia Manufacturing Industry)
}

\author{
YULIUS KURNIA SUSANTO \\ STIE Trisakti \\ yulius@stietrisakti.ac.id
}

\begin{abstract}
The purpose of the research is to get empirical evidence about institutional ownership, management ownership, directors' size, audit committee, independent commissioner, leverage, profitability, firm size, auditor's independency and auditor's reputability on earnings management practice. This research used 53 manufacturing companies listed in Indonesia Stock Exchange and the data were collected through purposive sampling method during the research period 2009 until 2011. The result of the research showed that audit committee, independent commissioner and debt to equity ratio had influence on earnings management practice. The results of this study indicate that the audit committee and independent commissioner overseeing management in reporting of company performance through financial statements. In addition, companies that source of funding more debt than equity is more likely to make an earnings management.
\end{abstract}

Keywords: Corporate governance, agency theory and earnings management.

Abstrak: Tujuan penelitian adalah untuk mendapatkan bukti empiris tentang kepemilikan institusional, kepemilikan managemen, ukuran direksi, komite audit, komisaris independen, leverage, profitabilitas, ukuran perusahaan, independensi auditor dan reputabilitas auditor terhadap praktik managemen laba. Penelitian ini menggunakan 53 perusahaan manufaktur yang terdaftar di Bursa Efek Indonesia dan data dikumpulkan melalui metoda purposive sampling selama periode penelitian 2009 sampai 2011. Hasil penelitian menunjukkan bahwa komite audit, komisaris independen dan debt to equity ratio memiliki pengaruh terhadap praktik managemen laba. Hasil penelitian menunjukkan bahwa komite audit dan komisaris independen mengawasi managemen dalam pelaporan kinerja perusahaan melalui laporan keuangan. Selain itu, perusahaan yang sumber pendanaan utang lebih besar dari ekuitas lebih mungkin untuk melakukan managemen laba.

Kata kunci: Corporate governance, teori keagenan dan managemen laba. 


\section{INTRODUCTION}

Information gain is the main focus in the financial reporting that provides information about a company's financial performance. The global crisis that hit the world in 2008, a major impact to the industry in Indonesia, many large companies are good financial performance but have problems in funding from both the stock and debt markets. It is estimated whether the company is actually really good or bad financial condition that is not visible from its financial statements. The issue is when it is sticking out of the practice of earnings management is performed by the management company, so the reliability of the information provided in the financial statements is decreased.

The financial statements should reflect the actual situation, but with the difference of interest between managers and investors make information becomes unbalanced or commonly referred to as information asymmetry. Corporate Governance is a set of mechanisms that limit the incidence of information asymmetry encourages earnings management practices (Dye 1998 in Darmawanti 2003). Corporate governance also provides a structure that facilitates the determination of the goals of a company as well as suggestions for monitoring performance (Darmawanti et al. 2004).

The purpose of the research was to obtain empirical evidence that the mechanisms of corporate governance, financial ratios, firm size and the external auditors affect earnings management practices. This study is expected to provide information for investors to pay more attention to the mechanisms of corporate governance, financial ratios, firm size and external auditors in both stocks and debt investing to avoid companies that perform earnings management practices.

Earnings management is the act or process to manage the rate of profit, revenue and costs by changing the accounting methods and estimates as well as the recognition, measurement and disclosure. In extreme that earnings management can be regarded as cosmetic, for managers to manipulate accruals without any cash flow consequences (Subramanyam et al. 2004 in Handy and Rachadi 2009). Under the rules of GAAP (General Accepted Accounting Principles), the company only uses accrual accounting, companies record transactions that do and/or other events in the company's books at the time of the onset of the event compared to the time of receipt or payment of money (Xie et al. 2005 in Pradipta 2011). This suggests that the nature of accrual accounting is causing management has ample opportunity to perform discretion in determining the actual earnings the company reported in each period.

Earnings management is a phenomenon that is difficult to avoid, the use of accrual accounting was as a communication tool between the parties concerned the opportunity to make the company's management to intervene in the preparation of financial statements, so that the earnings information displayed does not show the real condition of the company. Corporate governance mechanisms are an excellent way to ensure that management acts in the best interest of stakeholders (Hormati 2009). Corporate Governance is governance that explain the relationship between the various participants in a company that determines the direction and performance of the company (Monks \& Minow 2001 in Wardhani 2009). Good corporate governance can be defined as a system that regulates and controls the company to create value for stakeholders (Sulistyanto and Wibisono 2003 in Guna and Herawaty 2010). There are two things that are emphasized in this mechanisms, the first is the importance of shareholders' rights to obtain information correctly, accurately and timely. Second, the company must make disclosure of accurate, timely and transparent information on stakeholders. Corporate governance mechanisms include institutional ownership, managerial ownership, number of directors, audit committee and independent commissaries. 


\section{Institusional Ownership and Earnings Management}

Institutional ownership is ownership of company shares by financial institutions such as insurance companies, banks, pension funds and investment banking (Siregar and Utama 2006). The amount of ownership held by the controlling shareholder, it will improve the quality of corporate governance (Durnev and Kim 2003 in Hormati 2009). Institutional ownership has a very important role in minimizing agency conflicts that occur between managers and shareholders (Jensen and Meckling 1976). Institutional ownership may reduce earnings management practices, this can happen because institutional investors have more time to analyze investments and have access to more information than individual investors (Siller and Pound 1989, in Astuti 2004). Based on these descriptions, the hypothesis as follows:

$\mathrm{H}_{1}$ Institutional ownership affect earnings management practices.

\section{Managerial Ownership and Earnings Management}

Management stock ownership is held by the management in private and owned stock subsidiary companies and their respective affiliates (Susiana and Herawaty 2007). Management Ownership is the proportion of shareholders that management actively participate in corporate decision-making, such as directors and commissioners (Pujiati and Erman 2009). Large management ownership in the company would be very effective in monitoring the activities of the company, so this raises interesting possibilities if the magnitude proxy hooking percentage of management ownership on the increase in value of the company as well as the likelihood of earnings management practices. Managerial ownership is one of the mechanisms applied by the company to limit the opportunistic behavior of the management of the company in the form of earnings management (Midiastuty and Machfoedz 2003 in Wirawan 2010). Based on these descriptions, the hypothesis as follows:

$\mathrm{H}_{2}$ Managerial ownership affect earnings management practices.

\section{The number of Board of Director and Earnings Management}

Stewardship of limited liability company in Indonesia, adopts a two-body system, which is the board of commissioners and directors, both have the responsibility and authority of each according to its function as mandated in the statutes and laws (fiduciary responsibility). In the General Guidelines for Implementation of Corporate Governance in Indonesia explained that the basic principle of the company's board of directors as the organ is in charge and collegial responsibility in managing the company, is also expressed in the principal guideline implementation, that the composition of the board of directors, must be tailored to the complexity of the company with regard to the effectiveness in decision making. This is closely related to the duties, functions and responsibilities of directors in creating and managing the company's corporate governance mechanisms that lead.

The number of board of directors who is getting a bit more effective in controlling the practice of earnings management (Midiastuty and Machfoedz 2003 in Wirawan 2010). The number of board of directors considered not functioning optimally and can be controlled by the manager if more than 7 people (Jensen 1993 in Suhartini 2006). If the board of directors can be controlled by managers and occurs asymmetric information within the company, then the manager will be more flexibility in conducting earnings management (Suhartini 2006). Based on these descriptions, the hypothesis as follows:

$\mathrm{H}_{3}$ The number of Board of Directors affect earnings management practices.

\section{Audit Committee and Earnings Management}

The existence of an audit committee is essential for the management of the company. The audit committee is a new component in the control system of the company. In addition the audit committee is considered as a link between the shareholders and the board of commissioners with management in addressing the problem of 
control and audit committees assist the board of commissioners to oversee the management in the preparation of financial statements, so that with the audit committee of the company can reduce the occurrence of earnings management. The problems that occur in financial reporting can be reduced by the audit committee from outside the directorship (Song and Windram 2000 and Xie et al. 2003 in Utami and Rahmawati 2008). Based on these descriptions, the hypothesis as follows:

$\mathrm{H}_{4}$ Audit committee affect earnings management practices.

\section{Independent Ccommissioner and Earnings Management}

A growing number of independent commissioner in the company succeeded in reducing earnings management practices, this suggests an independent commissioner has effectively run its responsibility to oversee the quality of financial reporting limit earnings management practices (Utama and Rahmawati 2008). Companies with board members from outside the company will affect earnings management practices in the company (Pratana and Mas'ud 2003 and Xie et al. 2003 in Ujiyantho and Pramuka 2007). The use of discretionary accruals is reduced if the commissioners from outside supervision (Cornet et al. 2006 in Guna and Herawaty 2010). Based on these descriptions, the hypothesis as follows:

$\mathrm{H}_{5}$ Independent commissioner affect earnings management practices.

\section{Leverage and Earnings Management}

The proportion of the use of debt leverage to finance investments. The greater the debt of the company, the greater the risk faced by investors so that investors demanded higher rates of return (Sartono 2010). This happens because, the high level of leverage ratio means the company uses high debt anyway, and this means it is possible to increase the profitability of the company. But on the other hand, high debt if not managed properly will have the risk of bankruptcy is too big. This is why managers are encouraged to perform and consider earnings management practices. Companies that have high leverage means having more debt than assets that encourage managers conduct earnings management (Defond and Jimbalvo 1994 in Astuti 2004). Companies with high leverage tend to adjust reported earnings compared with companies that have low leverage (Dhaliwal 1980 in Astuti 2004). Based on these descriptions, the hypothesis as follows:

$\mathrm{H}_{6}$ Leverage affect earnings management practices.

\section{Profitability and Earnings Management}

Profitability is an important measure for assessing the company's healthy or not affecting the investor to make a decision (Suwito and Herawaty 2005), therefore the level of profitability can see the effectiveness of the company in generating profits. Profitability is characterized by the presence of the profit generated as an indicator of the company's performance in managing the wealth management company (Sudarmadji and Sularto 2007 in Guna and Herawaty 2010). Companies that perform earnings management are a company that has a smaller profitability of other companies that do not perform profitability (Ashari et al. 1994 in Herni and Susanto 2008). Based on these descriptions, the hypothesis as follows:

$\mathrm{H}_{7}$ Profitability affect earnings management practices.

\section{Firm Size and Earnings Management}

Companies that belong to the large scale and strategic industries tend to perform earnings management, especially in terms of lower earnings at the high level of prosperity, this is done to get the convenience of a government facility (Wirawan 2010). While the company is relatively small role in earnings management tend to do in terms of raising income, this is done in order to attract investors. Based on the description of the hypothesis as follows:

$\mathrm{H}_{8}$ Firm Size affect earnings management practices. 


\section{Auditor Independence and Earnings Management}

AICPA (Association International Certified

Public Accountant) argued that independence is an ability to act in accordance with the integrity and objectivity. Integrity is a moral attitude of an impartial, honest and looking to the fact it is, while independence is a state free from influence, not controlled by the other party and not depend on others. Auditor independence is very important in realizing corporate governance, given the opinion issued by the auditor of the company that inspected greatly affect the level of public trust. It is expected that the examination of accounting auditors in accordance with professional norms. Auditor independence is closely related to four things: the competition, the nonaudit services, auditor size and auditor tenure (Shockley 1981 in Meutia 2004). This is supported by Guna and Herawaty (2010) which says that the old assignment affects the auditor independence that may affect the practice of earnings management. Based on the description of the hypothesis as follows:

$\mathrm{H}_{9}$ Auditor independence affect earnings management practices.

\section{Auditor Reputation and Earnings Management}

To resolve possible conflicts of interest, and minimizing the likelihood of earnings management practices, it would require some supervision and contract mechanisms. Required third-party services so that the confidence level of external accountability given to the company management can be trusted as a basis for decision making. There are allegations that reputable auditors can detect the likelihood of earnings management earlier (Widyaningdyah 2001).

Auditors working in the Big Four Firm considered more qualified to perform the examination, because equipped with a variety of training, procedures and audit programs are more accurate than the non-Big Four Firm (Isnanta 2008). Audit quality can reduce the uncertainty of the financial statements presented by management. The selection of reputable auditors (big four) is the right choice to provide a signal to the reader that the financial statements have been reliably reported (Sanjaya 2008). This assumption arises because the big four firm is equipped with a series of training programs and procedures and have an accurate and effective (Guna and Herawaty 2010). Based on the description of the hypothesis as follows:

$\mathrm{H}_{10}$ Auditor reputation affect earnings management practices.

\section{METHODS}

The population used in this study are all listed manufacturing companies in Indonesia Stock Exchange (IDX). The sample in this study was obtained by purposive sampling method, the criterion of manufacturing companies that have been listed on the Indonesia Stock Exchange (IDX) consistently from 2009 to 2011, published financial statements using the currency, published financial statements as of December 31, audited, company that has a profit after tax as well as a positive cash flow from operating activities consecutively during the study period of three years and the company provides data on corporate governance to detect the possibility of earnings management practices. The number of companies that meet the sample selection criteria sample was 53 companies.

Institutional shareholding number is the percentage of shares held by financial institutions or other parties outside the company. Financial institutions in question are insurance companies, banks, pension funds, and investment banking (Guna and Herawaty 2010). Total Shareholding Management, are shares owned by management including the percentage of shares owned privately or by the subsidiary companies concerned and their affiliates (Guna and Herawaty 2010). Management Ownership is measured using a dummy variable, the number 1 to represent a company that has managerial ownership and 0 otherwise. The number of board of director, directors of a company in 
charge of organ and collegial responsibility in managing the company. Members of the board of directors is appointed and dismissed by the general meeting through a transparent process (NCG, 2006). This variable is measured by the proxy of the number of board members sitting in the office of directors in the company (Pradipta 2011). The audit committee according to Kep. 29/PM/2004 is a committee established to perform a task commissioner supervises the management of the company. The audit committee in this study was calculated using the number of audit committee members are contained in the company (Makhdalena 2011). Independent Commissioner is a commissioner that has nothing to do with management, other board members and controlling shareholders. Independent commissioner calculated by the scale ratio, ie the percentage of board members from outside the company of all members of the company's board of commissioners.

Leverage is a credit analysis, which is part of the analysis of capital structure and solvency ratios, which are used to assess the ability to meet long-term obligations (Subramanyam and Wild 2009). Leverage is proxied by the debt to equity ratio. Profitability is the indicator used to measure performance in managing the company, as indicated by the profits. Profitability measured by return on assets (ROA) is the ratio between net income and total assets. Firm size is the size that shows a large or small company. Firm size was measured by using a proxy for the size of a company in terms of the logarithm of total assets. Auditor Independence auditor assignment is measured by proxy using dummy variables, the number 1 is used if the company does not use the same auditor within 3 years and 0 otherwise. Auditor Reputation seen from the size of the firm where the auditor's work and can be divided into two criteria, namely the Big Four and non-Big Four. Auditor reputation is measured using a dummy variable, the number 1 is used if the companies audited by the Big Four Firm and 0 otherwise.
Discretionary accrual is the accrual component that allows managers to intervene in the process of preparing financial statements, so that the earnings reported in the financial statements do not reflect the value or condition of the actual company, this is because the manager has the capacity to control their profits in the short term (Guna and Herawaty 2010 ). Total accruals are composed of non-discretionary accruals and discretionary accruals. Value of discretionary accruals is the residual value of the results of the following regression:

$$
\mathrm{TAC}=\alpha_{1}+\alpha_{2} \boldsymbol{\Delta} \mathrm{REV}_{\mathrm{t}}+\alpha_{3} \mathrm{PPE}_{\mathrm{t}}+\mathrm{e}
$$

Information TACt Total Accruals in period $t$ (operating net income - operating cash flow), $\Delta R_{t}$ change of revenue from year $t-1$ and year $t, \mathrm{PPE}_{\mathrm{t}}$ gross property plant and equipment period t. All calculations are scaled by total assets in end period t-1.

\section{RESEARCH RESULT}

The results of descriptive statistics and hypothesis testing are as follows: 
Table 1 Descriptive Statistics

\begin{tabular}{lcclc}
\hline \multicolumn{1}{c}{ Variable } & Minimum & Maximum & Mean & Std. Deviation \\
\hline Institutional ownership & 0.2971 & 0.9974 & 0.7133 & 0.1808 \\
Managerial ownership & 0 & 1 & 0.43 & 0.497 \\
The number of board of director & 2 & 12 & 5.34 & 2.216 \\
Audit committee & 2 & 5 & 3.19 & 0.53 \\
Independent commissioner & 0.25 & 1 & 0.4088 & 0.1218 \\
Leverage & -1.4842 & 8.9951 & 0.9445 & 1.2641 \\
Profitability & 0.0003 & 0.8022 & 0.1184 & 0.1115 \\
Firm Size & 10.8437 & 14.1861 & 12.1418 & 0.6931 \\
Auditor independence & 0 & 1 & 0.82 & 0.382 \\
Auditor reputation & 0 & 1 & 0.53 & 0.501 \\
Earnings Management practices & -0.4708 & 0.3161 & $1.361510^{-17}$ & 0.0917 \\
\hline
\end{tabular}

Table 2 Result of Hypothesis Testing

\begin{tabular}{lccc}
\hline \multicolumn{1}{c}{ Variable } & B & Tolerance & VIF \\
\hline Constant & -0.001 & & \\
Institutional ownership & -0.033 & 0.883 & 1.133 \\
Managerial ownership & -0.014 & 0.782 & 1.279 \\
The number of board of director & 0.007 & 0.548 & 1.824 \\
Audit committee & $0.029 * *$ & 0.830 & 1.205 \\
Independent commissioner & $-0.115^{*}$ & 0.907 & 1.102 \\
Leverage & $-0.019 * * *$ & 0.896 & 1.117 \\
Profitability & 0.01 & 0.785 & 1.274 \\
Firm Size & -0.002 & 0.470 & 2.129 \\
Auditor independence & 0.007 & 0.950 & 1.052 \\
Auditor reputation & -0.023 & 0.441 & 2.268 \\
\hline *Sig. $<0.10, * *$ Sig. $<0.05, * * *$ Sig. $<0.01, \mathrm{~F}_{10,148}=2.822$ Sig.0.003, Adj. ${ }^{2}=0.103$.
\end{tabular}

Based on Table 2 shows that institutional ownership has no effect on earnings management practices. This is due to the number of institutional ownership in a company would encourage management to perform earnings management practices, to meet earnings targets institutional investors. The results of this study are consistent with research Pradipta (2011), Guna and Herawaty (2010) and Siregar and Utama (2005).

Management ownership does not affect the practice of earnings management. This is due to lack of companies that have the managerial ownership. Ownership of shares held managerial parties are not able to become a corporate governance mechanism that can reduce the misalignment of management with the interests of the owners or shareholders. The results of this study are consistent with research and Herawaty Guna (2010), Pradipta (2011) and Trisnawati (2009).

The number of board of director has no effect on earnings management practices. This means that the size of the board size has no effect on the optimal board of directors in detecting earnings management is carried out 
by the management. The results of this study are consistent with research Chtourou et al. (2001). The audit committee has an effect on earnings management practices. This means the existence of an audit committee of a company can detect earnings management practices in the company. Independent commissioner effect on profit management. This means that the presence of independent directors in a company is able to become one of the corporate governance mechanism in detecting earnings management. The greater the number of independent directors in the company, the better management oversight, which will reduce earnings management practices that are opportunistic.

Leverage effect on earnings management practices. This is due to the substantial leverage will encourage the management to pull through earnings management practices that are opportunistic, as investors tend to like companies with little leverage. The results of this study are consistent with research Pradipta (2011) and Suwito and Herawaty (2005). Profitability has no effect on earnings management practices. This is due to the investors to invest not only pay attention to the company's profit. They know that the earnings listed in the statement of income are accrued value that can be managed by a management company. Firm size has no effect on earnings management practices. This means that firm size has no effect on earnings management practices in terms of lower profits for large companies and increase profits for small companies.

Auditor independence has no effect on earnings management practices. The results of this study are consistent with research Guna and Herawaty (2010). This is caused by the inability of the auditor in identifying earnings management practices in a company through the process of auditing the financial statements of the company. Auditor reputation has no effect on earnings management practices. The results of this study are consistent with research Siregar and Utama (2005), Handayani and Rachadi (2009). This is caused by the Big Four auditors of the firm and non-Big Four have a series of training, procedures and programs are accurate and effective so as to detect the practice of earnings management in a company.

\section{CONCLUSION}

Based on the results of this study concluded that the audit committee, independent commissioner and the leverage effect on earnings management practices. While institutional ownership, managerial ownership, number of board of director, profitability, firm size, auditor independence and reputation have no effect on earnings management practices. This study has several limitations that should be considered in future studies, this study is just taking a threeyear study period is from 2009 to 2011 and a sample of manufacturing firms. Future studies are expected to add at least 5 years of the study period and non-financial companies listed on the Indonesia Stock Exchange. Additionally examine other factors that affect the practice of earnings management such as bonus compensation.

\section{REFERENCE:}

A. Nuraini and Sumarno Zain. 2007. Analisa Pengaruh Kepemilikan Institusional dan Kualitas Audit Terhadap Manajemen Laba. Jurnal Manajemen Akuntansi, Vol. 7, No. 1, Januari, pp. 19-32.

Anggraini, Fivi and Ira Trisnawati. 2008. Pengaruh Earnings Management terhadap Konservatisma Akuntansi. Jurnal Bisnis dan Akuntansi, Vol. 10, No. 1, pp. 23-36.

Assih, Prihat. 2009. Kualitas Auditor Ekstern Dalam Membatasi Kesempatan Manajemen Untuk Melakukan Manajemen Laba. Jurnal Keuangan dan Perbankan. Vol. 13, No. 3, pp. 462-474.

Astuti, Dewi S. Puji. 2004. Analisa Faktor-Faktor Yang Mempengaruhi Motivasi Manajemen Laba Diseputar Right Issue. Jurnal Riset Akuntansi Indonesia, Vol. 7, No. 2, Mei, pp. 251-263. 
Azlina, Nur. 2010. Analisa Faktor-Faktor yang Mempengaruhi Manajemen Laba. Perekonomian Bisnis Jurnal, Vol. 2, No. 3, November, pp. 355-363.

Bangun, N. and Vincent. 2008. Analisis Hubungan Komponen Good Corporate Governance Terhadap Manajemen Laba Dengan Kinerja Keuangan Pada Perusahaan Manufaktur Yang Terdaftar di Bursa Efek Indonesia. Jurnal Akuntansi/Tahun XII, No. 3, September, pp. 289-302.

Budiasih, Igan. 2009. Faktor-Faktor yang Mempengaruhi Praktik Perataan Laba. Jurnal Akuntansi dan Bisnis, Vol. 4 No. 1, pp. 44-50.

Chtourou, Sonda Marrakachi, Jean Bedard and Lucie Courteau. 2001. Corporate Governance and Earning Management. http://papers.srrn.com/abstract=275053.

Darmawanti, D. and Khomsiyah, Rahayu, Gelar Rika. 2004. Hubungan Corporate Governance dan Kinerja Perusahaan. http://www.iicg.org/asset/doc/CG\&Kinerja-DDA,KSY,RGR.pdf.

Darmawanti, Deni. 2003. Corporate Governance dan Manajemen Laba : Suatu Studi Empiris. Jurnal Bisnis dan Akuntnasi. Vol. 5, No. 1, pp. 47-68.

Effendi, Muh. Arief. 2005. Peranan Komite Audit dalam Meningkatkan Kinerja Perusahaan. Jurnal Akuntansi Pemerintah. Vol. 1, pp. 51-57.

Farida, Yusriati Nur, Yuli Prasetyo and Eliada Herwiyanti. 2010. Pengaruh Penerapan Corporate Governance terhadap Timbulnya Earnings Management dalam Menilai Kinerja Keuangan pada Perusahaan Perbankan di Indonesia. Jurnal Bisnis dan Akuntansi, Vol. 12 No. 2, pp. 69-80.

Fitriasari, Debby. 2007. Pengaruh Aktivitas dan Financial Literacy Komite Audit terhadap Jenis Manajemen Laba. Simposium Nasional Akuntansi, Makasar, 26-28 Juli.

Godfrey, Jayne, Alan Hodgson, Ann Tarca, Jane Hamilton and Scott Holmes. 2010. Accounting Theory. $7^{\text {th }}$ edition. Australia : John Wiley \& Sons Australia, Inc.

Guna, W. I. and Arleen H. 2010. Pengaruh Mekanisme Good Corporate Governance, Independensi Auditor, Kualitas Audit, dan Faktor Lainnya Terhadap Manajemen Laba. Jurnal Bisnis dan Akuntansi, Vol. 12, No. 1, April, pp. 53-68.

Handayani, RR. Sri and Agustono Dwi Rachadi. 2009. Pengaruh Ukuran Perusahaan terhadap Manajemen Laba. Jurnal Bisnis dan Akuntansi, Vol. 11, No. 1, pp. 33-56.

Hardiningsih, RR. Sri and Agustono Dwi Rachadi. 2009. Corporate Governance dan Kualitas Audit Terhadap Integritas Laporan Keuangan. Kajian Akuntansi, Vol. 2, No. 1, Febuari, pp. 61-76.

Harahap, Sofyan Syafri. 2004. Teori Akuntansi, Edisi Revisi. Jakarta: PT. Raja Grafindo Persada.

Herni and Yulius K. Susanto. 2008. Pengaruh Struktur Kepemilikan Publik, Praktik Pengelolaan Perusahaan, Jenis Industri, Ukuran Perusahaan, Profitabilitas dan Risiko Keuangan Terhadap Tindakan Perataan Laba (Studi Empiris Pada Industri Yang Listing di Bursa Efek Indonesia). Jurnal Ekonomi dan Bisnis Indonesia, Vol. 23, No. 3, Juli, pp. 302-314.

Herusetya, Antonius. 2009. Efektifitas Pelaksanaan Corporate Governance dan Audit Eksternal-Auditor dengan Spesialisasi Industri dalam Menghambat Manajemen Laba. Jurnal Akuntansi dan Auditing Indonesia, Vol. 13, No. 2, Desember.

Hormati, Asrudin. 2009. Karakterisik Perusahaan Terhadap Kualitas Implementasi Corporate Governance. Jurnal Keuangan dan Perbankan. Vol. 13. No.2, Mei.

Hwihanus and Hambur Qurba. 2010. Faktor-faktor yang Mempengaruhi Manajemen Laba pada Perusahaan Industri yang Terdaftar di Bursa Efek Indonesia. Jurnal Ekonomi dan Bisnis, Vol. 14, No. 1, pp. 1-6.

Institut Akuntan Publik Indonesia. 2011. Standar Profesional Akuntan Publik. Jakarta: Salemba Empat.

Ifada, Luluk M. and Gigih Kurniawan. 2011. Mekanisme Corporate Governance, Manajemen Laba dan Kinerja Keuangan. EKOBIS, Vol. 12 No. 1, pp. 27-39.

Isnanta, R. 2008. Skripsi Pengaruh Corporate Governance dan Struktur Kepemilikan Terhadap Manajemen Laba dan Kinerja Keuangan. http://rac.uii.ac.id/server/document/public/ 2008080708584504312069.pdf.

Jensen, Michael C and William H Meckling. 1976. Theory of the Firm: Managerial Behaviour, Agency Cost and Ownership Structure. Journal of Financial Economics, Vol 3.

Kusuma, Hadri and Sari, Wigiya A. U. 2003. Manajemen Laba Oleh Perusahaan Pengakuisisi Sebelum Merger dan Akuisisi di Indonesia. Jurnal Auditing Akuntansi, Vol. 7, No. 1, Juni, pp. 21-36. 
Lugihatno. 2010. Analisa Pengaruh Kualitas Audit Terhadap Manajemen Laba Studi Pada Perusahaan Yang Melakukan IPO di Indonesia. Fokus Ekonomi, Vol. 5, No. 2, Desember, pp. 15-31.

Mahmudi. 2001. Manajemen Laba (earnings management) Sebuah Tinjauan Etika Akuntansi. Jurnal Bisnis dan Akuntansi, Vol. 3 No. 2, 395-402.

Makhdalena. 2009. Hubungan Komite Audit dengan Internal Control. Jurnal akuntansi, Vol. 4, No. 2.

Makhdalena. 2011. Hubungan Komposisi Komite Audit Dengan Earnings Management (Studi pada Emiten Manufaktur di Bursa Efek Jakarta). Jurnal Akuntansi, Vol. XV, No. 02, Mei, pp. 138-148.

Mar'uf, Muhammad. 2006. Analisis Faktor-Faktor yang Mempengaruhi Manajemen Laba Pada Perusahaan Go Public di Bursa Efek Jakarta. www.rac.uii.ac.id/server/document/public/ 2008505023540013212114.pdf.

Mayangsari, Sekar. 2003. Analisis Pengaruh Independensi, Kualitas Audit, serta Mekanisme Corporate Governance Terhadap Integritas Laporan Keuangan. Simposium Nasional Akuntansi VI. pp. 1255-1269.

Meutia, Inten. 2004. Pengaruh Independensi Auditor Terhadap Manajemen Laba Untuk KAP BIG 5 dan Non BIG 5. Jurnal Riset Akuntansi Indonesia. Vol.7. No.3. September, pp. 333-350.

Midiastuty, Pranata P. and Mas'ud Machfoedz. 2003. Analisis Hubungan Mekanisme Good Corporate Governance dan Indikasi Manajemen Laba. Simposium Nasional Akuntansi VI. pp. 176-186.

Nasser, Etty M. 2008. Pengaruh Struktur Kepemilikan dan Dewan Komisaris Independen terhadap Nilai Perusahaan dengan Manajemen Laba dan Kebijakan Hutang sebagai Variable Intervening. Media Riset Akuntansi, Auditing, dan Informasi, Vol. 8 No. 1, 1-27.

Nasution, Marihot and Doddy Setiawan. 2007. Pengaruh Corporate Governance terhadap Manajemen Laba di Industri Perbankan Indonesia. Simposium Nasional Akuntansi, Makasaar, 26-28 juli 2007.

Nini and Estralita T. 2009. Pengaruh Independensi Auditor Pada KAP Big Four Terhadap Manajemen Laba pada Industri Bahan Dasar, Kimia, dan Industri Barang Konsumsi. Jurnal Bisnis dan Akuntansi, Vol. 11, No. 3 , Desember, pp. 175-188.

Nuraini, A and Sumarno Zain. 2008. Analisis Pengaruh Kepemilikan Institusional dan Kualitas Audit terhadap Manajemen Laba. Jurnal MAKSI, Vol. 13 No. 2, November.

Pamudji, Sugeng and Aprillya Trihartati. 2010. Pengaruh Independensi dan Efektivitas Komite Audit terhadap Manajemen Laba. Jurnal Dinamika Akuntansi, Vol. 2, No. 1, pp. 21-29.

Payamta (2006) Pengaruh Kualitas Auditor, Independensi, dan Opini Audit Terhadap Kualitas Laporan Keuangan. Jurnal Bisnis dan Manajemen, Vol. 6, No. 1, pp. 81-96.

Pedoman Umum Good Corporate Governance Indonesia. 2006. Komite Audit Nasional Kebijakan Covernance.

Pradipta, Arya. 2011. Analisis Pengaruh dari Mekanisme Corporate Governance Terhadap Manajemen Laba. Jurnal Bisnis dan Akuntansi, Vol. 13, No.2, Agustus, pp. 93-106.

Primanita and Setiono. 2006. Manajemen laba : Konsep, Bukti Empiris dan Implikasinya. Sinergi Kajian Bisnis dan Manajemen, Vol. 8, No. 1, pp. 43-51.

Pujiati, D. and Erman Widanar. 2009. Pengaruh Struktur Kepemilikan Terhadap Nilai Perusahan: Keputusan Keuangan Sebagai Variabel Intervening. Jurnal Ekonomi Bisnis dan Akuntansi Ventura. Vol. 12, No. 1, pp. 71-86.

Rahman, R. A. 2006. Board, Audit Committee, Culture and Earnings Management: Malaysian Evidence. Managerial Auditing Journal, Vol. 21, No. 27, pp. 783-801.

Rahmawati, Yacob Suparno and Nurul Qomariyah. 2006. Pengaruh Asimetris Informasi terhadap Praktik Manajemen Laba pada Perusahaan Perbankan Publik yang terdaftar di Bursa Efek Indonesia. Simposium Nasional Akuntansi 9, padang, 23-26 Agustus.

Restuningdiah, Nurika. 2011. Komisaris Independen, Komite Audit, Internal Audit, dan Risk Management Committee terhadap Manajemen Laba. Jurnal Keuangan dan Perbankan, Vol. 15 No. 3, pp. 351-362.

Rusmin, Rusmin. 2010. Auditor quality dan earnings management: singaporean evidence. Managerial auditing journal, Vol. 25 No. 7, pp. 618-638.

Sanjaya, I. P. S. 2008. Auditor Eksternal, Komite Audit, dan Manajemen Laba. Jurnal Riset Akuntansi Indonesia, Vol.11, No.1, Januari, pp. 97-116.

Sartono, Agus, 2010. Manajemen Keuangan, Edisi ke 4. Yogyakarta: BPFE

Sekaran, Uma and Roger Bougie. 2010. Research Methods for Business: A Skill Building Approach. $5^{\text {thed. West }}$ Sussex: JhonWiley \& Sons Ltd. 
Siregar, Sylvia Veronica and Yanivi S., Bachtiar. 2004. Hubungan Antara Manajemen Laba dengan Tingkat Pengungkapan Laporan Keuangan. Simposium Nasional Akuntansi VI, pp. 328 -349.

Siregar, Sylvia Veronica and Utama, S. 2006. Pengaruh Struktur Kepemilikan, Ukuran Perusahaan, dan Prektek Corporate Governance terhadap Pengelolaan Laba (Earning Manajemen). Jurnal Riset Akuntansi Indonesia, Vol. 19, №. 3, pp. 307 - 326.

Siswanto, J. F. A. 2009. Kebijakan Manajemen Laba. Fokus Ekonomi, Vol. 8, No. 1, April, pp. 7-13.

Subramanyam, K.R. and John J. Wild. 2009. Financial Statment Analysis. USA. Mc Graw - Hill International Edition.

Suhartini, Dwi. 2006. Pengaruh Leverage, Jumlah Dewan Direksi, Reputasi Auditor, dan Persentase Saham Yang Ditawarkan Pada Publik Saat IPO Terhadap Earnings Management. Jurnal IImu-IImu Ekonomi, Vol. 6., No. 2, September, pp. 64-75.

Suhartini, Dwi. 2006. Pengaruh Leverage, Jumlah Dewan Direksi, Reputasi Auditor dan Presentase Saham yang Ditawarkan pada Publik saat IPO terhadap Earning Management. Jurnal IImu-IImu Ekonomi, Vol. 6 No. 2, pp. 64-75.

Sukartha Made. 2007. Pengaruh Manajemen Laba, Kepemilikan Manajerial, dan Ukuran Perusahaan Pada Kesejahteraan Pemegang Saham Perusahaan Target Akuisisi. Jurnal Riset Akuntansi Indonesia, Vol. 10, No. 3, September, pp. 243-267.

Susiana and Herawaty, A. 2007. Analisis Pengaruh Independensi, Mekanisme Corporate Governance, dan Kualitas Audit terhadap Integritas Laporan Keuangan. Simposium National Akuntansi X, 26-48 Juli, Unhas Makasar.

Suwito, E. and A. Herawaty. 2005. Analisis Pengaruh Karakteristik Perusahaan Terhadap Tindakan Perataan Laba Yang Dilakukan Oleh Perusahaan Yang Terdaftar di Bursa Efek Jakarta. Simposium Nasional Akuntansi VIII, Solo, 15-16 September.

Tiswiyanti, Wiwik, Dewi Fitriyani and Wiralestari. 2012. Analisis Pengaruh Komisaris Independen, Komite Audit dan Kepemilikan Institusional terhadap Manajemen Laba. Jurnal Penelitian Universita Jambi, Vol. 14 No. 1, pp. 61-66.

Trisnawati, Rina. 2009. Perbedaan Mekanisme Corporate Governance dan Praktik Manajemen Laba : Studi Komparasi Indeks Syari'ah dan Indeks Konvensional di Bursa Efek Indonesia. UNISA, Vol. 32, No. 72. Desember.

Ujiyantho, Muh. A. and Bambang A. Pramuka. 2007. Mekanisme Corporate Governance, Manajemen Laba dan Kinerja Keuangan. Simposium Nasional Akuntansi X. Makasar. Juli.

Utami, Rini Budi and Rahmawati. 2008. Pengaruh Komposisi Dewan Komisaris dan Keberadaan Komite Audit Terhadap Aktivitas Manajemen Laba Pada Perusahaan Manufaktur Yang Terdaftar Di Bursa Efek Jakarta. Prosiding Seminar Ketahanan Ekonomi Nasional (SKEN) UPN "Veteran" Yogyakarta. Oktober, pp. 305-321.

Wedari, Linda K. 2004. Analisis Pengaruh Proporsi Dewan Komisaris dan Keberadaan Komite Audit Terhadap Aktivitas Manajemen Laba. Simposium Nasional Akuntansi VII. pp. 963-978.

Widyaningdyah, Agnes Utari. 2001. Analisa Faktor-Faktor yang Berpengaruh Terhadap Earnings Management Pada Perusahaan Go Public di Indonesia. Jurnal Akuntansi \& Keuangan, Vol. 3, No. 2, November, pp. 89-101.

Widyastuti, Tri. 2007. Pengaruh Karakteristik Perusahaan terhadap Manajemen Laba dan Dampaknya pada Return Saham. Akuntabilitas, Vol. 7 No. 1, pp. 38-44.

Widyastuti, Tri. 2009. Pengaruh Struktur Kepemilikan dan Kinerja Keuangan Terhadap Manajemen Laba Studi Pada Perusahaan Manufaktur di Bursa Efek Indonesia. Jurnal Maksi, Vol. 9, No. 1, Januari, pp. 30-41.

Wirawan, Saldy. 2010. Pengaruh Struktur Corporate Governance, Kontrak Hutang dan Political Cost Terhadap Manajemen Laba Pada Perusahaan Manufaktur Periode 2006-2009. Media Riset Akuntansi, Auditing, \& Informasi, Vol. 1, No. 3, Desember, pp. 1-14.

Yushita, Amanita Novi. 2010. Earnings Management dalam Hubungan Keagenan. Jurnal Pendidikan Akuntansi Indonesia, Vol. VIII, No. 1, pp. 53-62. 